Media Komunikasi dan Informasi Hukum dan Masyarakat

Voume : 18 , Nomor : 3

ISSN Online : 2613-9340

ISSN Offline : 1412-1255

\section{PENERAPAN SANKSI HUKUM PIDANA TERHADAP PELAKU TINDAK PIDANA PECURIAN HEWAN TERNAK}

\section{Oleh:}

\section{Cut Nurita ${ }^{1}$}

\section{Abstract}

The criminal act of theft is still a dilemma, and this seems a quite serious problem which requires any solution. The problems in this study are what factors cause the theft of livestock, and how the implementation of criminal legal sanctions is against the perpetrators of theft.

This study uses descriptive methods through normative approach (legal research), which is based on the facts in the field approach to the problem, and is carried out by examining various legal aspects in terms of applicable regulations.

The finding shows that the factors that cause the theft of livestock are economic factors, low appreciation to religion, family factors, environmental / social factors, unemployment, influence of mass media either TV or foreign films, influence of alcohol, and opportunity factor. In addition to these factors, there are objective factors and subjective factors. The implementation of criminal legal sanctions for the perpetrators of the theft is regulated in Article 363 of the Criminal Code.

Keywords: Criminal Act, Theft, Livestock

Abstrak
Tindak pidana pencurian sampai saat ini masih
dilematis dan menjadi masalah yang cukup
serius serta memerlukan pemecahan.
Hukum Benteng Huraba
Permasalahan dalam jurnal ini adalah bagaimana faktor-faktor yang menyebabkan terjadinya tindak pidana pencurian hewan ternak, bagaimana penerapan sanksi hukum pidana terhadap pelaku tindak pidana pencurian hewan ternak.

Penelitian ini menggunakan metode deskriptif melalui pendekatan normatif (legal research) yaitu berdasarkan fakta di lapangan pendekatan terhadap permasalahan, dilakukan dengan mengkaji berbagai aspek hukum dari segi peraturan-peraturan yang berlaku.

Hasil penelitian menunjukkan bahwa Faktorfaktor yang menyebabkan terjadinya tindak pidana pencurian hewan ternak adalah faktor ekonomi faktor ekonomi, rendahnya penghayatan agama, faktor keluarga, faktor lingkungan/pergaulan, akibat pengangguran, pengaruh media massa khususnya tv dan film asing, pengaruh alcohol, faktor kesempatan. Selain faktor tersebut terdapat faktor-faktor lainya seperti faktor objektif dan faktor subjektif, Penerapan sanksi hukum pidana terhadap pelaku tindak pidana pencurian hewan diatur dalam Pasal 363 KUHP.

\section{Kata Kunci : Tindak Pidana, Pencurian, Ternak}

\section{Pendahuluan}

\section{A. Latar Belakang}

Seiring perkembangan zaman dan kemajuan di seluruh sendi kehidupan, manusia dituntut mengembangkan dirinya untuk dapat mengikuti perkembangan zaman tersebut. Manusia sebagai makhluk yang paling sempurna, masing-masing dianugerahi oleh Tuhan akal budi dan nurani yang memberikan kepadanya kemampuan untuk membedakan yang baik dan yang buruk yang akan 
Media Komunikasi dan Informasi Hukum dan Masyarakat

membimbing dan mengarahkan sikap dan perilaku dalam menjalani kehidupannya serta masing-masing diberikan bakat yang nantinya akan digunakan dalam rangka aktualisasi diri. Dengan akal budi, nurani, dan bakat yang dimilikinya itu, maka manusia memiliki kebebasan untuk memutuskan sendiri perilaku, perbuatan, dan dalam hal apa mereka dapat merealisasikan bakat yang mereka miliki tersebut. $^{2}$

Kehidupan sehari-hari di zaman modern ini, banyak terlihat dampak dari kemajuan zaman, baik itu dampak positif maupun dampak negatif. Dampak positifnya dapat terlihat dengan pesatnya kemajuan dalam dunia teknologi yang sangat membantu manusia dalam melakukan segala kegiatannya dalam kehidupan seharihari. Secara tidak langsung, pesatnya perkembangan zaman juga memiliki dampak negatif, hal ini dapat dilihat dengan banyaknya penyimpangan-penyimpangan yang timbul dalam kehidupan sehari-hari berupa kejahatan dan pelanggaran hukum yang sudah dilakukan oleh semua kalangan, dan para kaum remaja khususnya. Dalam beberapa tahun terakhir ini, pelanggaran terhadap peraturan-peraturan dan norma-norma yang berlaku semakin mengalami peningkatan. Hal ini tampak dari banyaknya kasus-kasus kejahatan yang diberitakan di berbagai media, baik media cetak maupun media elektronik. Maraknya pelanggaran terhadap norma-norma hukum yang berlaku tersebut merupakan salah satu kejadian dan fenomena sosial yang sering terjadi dalam masyarakat belakangan ini.

Negara Indonesia adalah negara yang berdasarkan atas hukum (rechsstaat), tidak berdasarkan atas kekuasaan belaka

2 Soerjono Soekanto, Sosiologi Suatu Pengantar, Raja Grafindo Persada, Jakarta, 2007, h..321. (machtsstaat). Pernyataan tersebut secara tegas tercantum dalam Penjelasan umum Undang-Undang Dasar 1945. Hal ini menjukkan bahwa indonesia adalah negara Hukum, Indonesia menerima hukum sebagai suatu ideologi untuk menciptakan ketertiban, keamanan, keadilan, serta kesejahteraan bagi warga negaranya. Konsekuensi dari itu semua adalah bahwa hukum mengikat setiap tindakan yang dilakukan oleh warga negara Indonesia. ${ }^{3}$ Hukum bekerja dengan cara memberikan petunjuk tentang tingkah laku dan karena itu pula hukum berupa norma. Hukum yang berupa norma dikenal dengan sebutan norma hukum,dimana hukum mengikat diri pada masyarakat sebagai tempat bekerjanya hukum tersebut. Hukum sendiri sangat erat kaitannya dengan kejahatan sebagai salah satu aspek yang terdapat dalam hukum terutama hukum pidana.

Indonesia sebagai negara hukum, maka hukum merupakan tiang utama dalam menggerakkan sendi-sendi kehidupan bermasyarakat, berbangsa dan bernegara. Oleh karena itu, salah satu ciri utama dari suatu negara hukum terletak pada kecenderungannya untuk menilai tindakan-tindakan yang dilakukan oleh masyarakat atas dasar peraturan-peraturan hukum. Artinya bahwa sebuah negara dengan konsep negara hukum selalu mengatur setiap tindakan dan tingkah laku masyarakatnya berdasarkan atas undang-undang yang berlaku untuk menciptakan, memelihara dan mempertahankan kedamaian pergaulan hidup, agar sesuai dengan apa yang diamanatkan dalam Pancasila dan UUD 1945 yaitu setiap

${ }^{3}$ C.T.S Kansil.Pengantar IImu Hukum dan Tata Hukum Indonesia. Balai Pustaka, Jakarta, 1998, hal. 346. 
Media Komunikasi dan Informasi Hukum dan Masyarakat

warga negara berhak atas rasa aman dan bebas dari segala bentuk kejahatan. ${ }^{4}$

Keberadaan hukum di tengah-tengah masyarakat sangat urgen, oleh sebab itu masyarakat harus memiliki kesadaran hukum yang hanya dapat dilihat dari indikatornya yang terdiri dari pengetahuan umum, pemahaman kaidah-kaidah hukum, sikap terhadap normanorma hukum dan perilaku hukum. ${ }^{5}$ Apabila masyarakat menginginkan kedamaian, ketentraman, keadilan dan kesejahteraan maka syarat utamanya adalah memenuhi kaidahkaidah hukum disamping sikap-sikap lain yang mendukung.

Meskipun segala tingkah laku dan perbuatan telah diatur dalam setiap Undangundang, kejahatan masih saja marak terjadi di negara ini. Kejahatan adalah perbuatanperbuatan yang melanggar norma- norma yang berlaku dalam masyarakat. Kejahatan secara yuridis adalah semua perbuatan manusia yang memenuhi perumusan ketentuan-ketentuan yang disebutkan dalam KUHP. ${ }^{6}$ Masalah kejahatan tidak lepas dari kehidupan bermasyarakat dimana merupakan salah satu bagian dari kehidupan manusia yang berlangsung terus-menerus. Kenyataan menunjukkan bahwa hampir setiap hari dalam media massa, baik media cetak maupun elektronik memuat berita tentang kejahatan.

Masalah kejahatan dalam masyarakat mempunyai gejala yang sangat kompleks dan rawan serta senantiasa menarik untuk dibicarakan. Hal ini dapat dipahami karena persoalan kejahatan tersebut merupakan

4 Mochtar KusumaAtmadja, Konsep-Konsep Hukum Dalam Pembangunan, Alumni, Bandung, 2002, hal. 17.

${ }^{5}$ Ibid, hal. 18.

${ }^{6}$ Kartini Kartono, Patalogi Sosial Jilid I, PT Raja Grafindo Persada, Jakarta, 2003, hal. 125. tindakan yang merugikan dan bersentuh langsung dengan kehidupan manusia, oleh karena itu diperlukan upaya-upaya untuk mencegah dan memberantas kejahatan yang dilakukan kendati kejahatan pembunuhan yang akhir-akhir ini menunjukkan perkembangan yang cukup meningkat.

Berdasarkan sosiologi, kejahatan disebabkan karena kondisi-kondisi dan prosesproses sosial yang sama,yang menghasilkan perilaku-perilaku sosial lainnya. analisis terhadap kondisi dan proses-proses tersebut menghasilkan dua Kesimpulan, yaitu terdapat hubungan antara variasi angka kejahatan dengan variasi organisasi-organisasi sosial dimana kejahatan tersebut terjadi. Tinggi rendahnya angka kejahatan berhubungan erat dengan bentuk-bentuk dan organisasiorganisasi sosial dimana kejahatan tersebut terjadi.

Secara universal, manusia mempunyai kebutuhan yang selalu ingin terpenuhi, termasuk kebutuhan sandang dan pangan, baik sebagai alat untuk memperoleh mempertahankan kehidupan, maupuan hanya sebatas pemenuhan hasrat ingin memiliki atau bahkan sebagai peningkatan status sosial (taraf hidup). Dengan bekerja diharapkan pemenuhan kebutuhan ini menjadi sebuah hal legal, bahkan bernilai ibadah dalam agama. Namun harapan itu tidak selamnya terpenuhi karena beragamnya sifat dan cara pemenuhan kebutuhan sandang dan pangan manusia yang terkadang menghalalkan segala cara, termasuk melakukan tindak pidana pencurian.

Seseorang melakukan tindak pidana pencurian tentu memiliki alasan yang berbedabeda, termasuk alasan ekonomi/faktor ekonomi, dengan faktor ekonomi dapat mendesak orang 
Media Komunikasi dan Informasi Hukum dan Masyarakat

untuk melakukan tindakan apapun termasuk tindak pidana pencurian.

Tindak pidana pencurian sampai saat ini masih dilematis dan menjadi masalah yang cukup serius serta memerlukan pemecahan, oleh karena itu diperlukan usaha penanggulangan atau setidak-tidaknya pencegahan yang baik dari semua pihak, baik aparat hukum maupun masyarakat yang harus diidentifikasikan agar dapat berjalan secara tertib, terarah, dan terencana. Dalam hal ini semua pihak harus bekerja sama dalam mengaktualisasikan nilai-nilai agama, budaya dan hukum serta menindak tegas para pelaku pencurian agar sedapat mungkin bisa menekan laju perkembanganya, karena bukan tidak mungkin pencurian akan terus bertambah dimasa-masa yang akan datang, bahkan akan menjadi fenomena yang biasa dalam masyarakat, sehingga semakin banyak orang yang harus menjadi korban perbuatan orangorang yang tidak bertanggung jawab.

Salah satu bentuk tindak pencurian adalah pencurian ternak sebagaimana dalam perkara putusan Nomor 867/Pid.B/2014/PN Rap, dimana pelaku terbukti tindak pidana pencurian ternak sebagaimana diatur dalam Pasal 363 ayat (1) ke-1, 4 KUHPidana. Pencurian tersebut dilakukan dengan cara pelaku mendatangi 1 (satu) ekor ternak lembu yang diikat di pohon kelapa sawit di samping rumah dan selanjutnya dibawa ke perbatasan perkebunan PT. Smart Padang Halaban dengan Dusun III Paret Minyak Desa Aek Korsik Kecamatan Aek Kuo Kabupaten Labuhanbatu Utara kemudian pelaku memukul kepala ternak lembu tersebut dengan potongan kayu bulat yang panjangnya sekitar 1(satu) meter hingga ternak lembu tersebut jatuh dan kemudian pelaku memotong bagian leher lembu tersebut lalu mengeluarkan isi perutnya kemudian dipotong menjadi 3 (tiga) bagian yaitu kepala, bagian kaki depan sebelah kanan dan kiri dan bagian kaki belakang sebelah kanan dan kiri, selanjutnya terdakwa memasukkan potongan ternak tersebut ke dalam keranjang gandeng yang terbuat dari kawat besi beton yang sebelumnya telah dipersiapkan oleh lalu menaikkannya ke sepeda motor.

Berdasarkan latar belakang di atas, maka dipilih judul tentang: "Penerapan Sanksi Hukum Pidana Terhadap Pelaku Tindak Pidana Pecurian Hewan Ternak".

\section{B. Perumusan Masalah}

Berdasarkan uraian pada latar belakang di atas, maka permasalahan yang akan diteliti dibatasi sebagai berikut:

1. Apa faktor-faktor yang menyebabkan terjadinya tindak pidana pencurian hewan ternak ?

2. Bagaimana penerapan sanksi hukum pidana terhadap pelaku tindak pidana pecurian hewan ternak?

\section{Metode Penelitian}

Penelitian ini bersifat deskriptif analitis, ${ }^{7}$ maksudnya adalah penelitian ini merupakan penelitian yang menggambarkan, menelaah, menjelaskan serta menganalisa permasalahan dalam tindak pidana pencurian ternak yang dihubungkan dengan peraturan perundangundangan yang kemudian dilakukan analisis. Penelitian ini merupakan suatu kegiatan ilmiah yang didasarkan pada metode, sistematika dan pemikiran tertentu yang bertujuan untuk

${ }^{7}$ Bambang Waluyo, Penelitian Hukum Dalam Praktek, Sinar Grafika, Jakarta, 1996, hal. 8. 
Media Komunikasi dan Informasi Hukum dan Masyarakat

mempelajari suatu hukum tertentu dengan jalan menganalisanya.

Berdasarkan objek penelitian yang merupakan hukum positif, maka metode pendekatan yang dipergunakan dalam penelitian ini adalah pendekatan yuridis normatif. ${ }^{8}$ Sebagai suatu penelitian yuridis normatif, maka penelitian ini juga dilakukan dengan menganalisis hukum baik tertulis di dalam buku (law as it writeen in the book) maupun hukum yang diputuskan oleh hakim melalui proses pengadilan (law as it is decided by the judge through judicial process) atau yang sering disebut dengan penelitian doktinal. $^{9}$

Pengumpulan data dalam penelitian ini mempergunakan data primer dan data sekunder.Penelitian ini menggunakan bahan yang diperoleh dari hasil penelitian kepustakaan. Dari penelitian kepustakaan dikumpulkan data sekunder yang meliputi bahan hukum primer, bahan hukum sekunder dan bahan hukum tertier.

Penelitian normatif, data yang diperlukan adalah data sekunder. Data sekunder tersebut mempunyai ruang lingkup yang sangat luas, sehingga meliputi surat-surat pribadi, buku-buku harian, sampai pada dokumen-dokumen resmi yang dikeluarkan oleh pemerintah. ${ }^{10}$

Data sekunder dalam penelitian ini terdiri dari:

8 Bambang Sunggono, Metodologi Penelitian Hukum, Raja Grafindo Persada, Jakarta, 1997, hal. h. 36

9 Bismar Nasution, Metode Penelitian Hukum Normatif dan Perbandingan Hukum, Makalah disampaikan pada Dialog Interaktif tentang Penelitian Hukum dan Hasil Penulisan Hukum pada Majalah Akreditasi, Fakultas Hukum USU, Medan, Tanggal 18 Pebruari 2003, hal. 1.

${ }_{10}$ Abdul Kadir Muhammad, Hukum dan Penelitian Hukum, Citra Aditya Bakti, Bandung, 2004, hal. 122. a. Bahan hukum primer yakni bahan hukum yang terdiri atas peraturan perundangundangan yang berkaitan dengan tindak pidana pencurian ternak.

b. Bahan hukum sekunder adalah bahanbahan yang erat kaitannya dengan bahan hukum primer berupa putusan-putusan Pengadilan, buku-buku yang berkaitan dengan objek yang diteliti.

c. Putusan-putusan pengadilan yang dipergunakan dalam penelitian ini adalah sejumlah putusan dengan memperhatikan tujuan penelitian ini dan dengan melihat ciriciri dan sifat-sifat dari objek yang diteliti dan hasilkan nanti akan digeneralisasikan.

Data sekunder yang diperoleh disusun secara sistimatis dan kemudian subtansinya dianalisis secara yuridis untuk memperoleh gambaran tentang pokok permasalahan.

\section{Hasil dan Penelitian}

A. Faktor-Faktor Yang Menyebabkan Terjadinya Tindak Pidana Pencurian Hewan Ternak

Status sosial seseorang di dalam masyarakat banyak dipengaruhi oleh beberapa faktor. Selama di dalam masyarakat itu ada sesuatu yang dihargai maka selama itu pula ada pelapisan-pelapisan di dalamnya dan pelapisanpelapisan itulah yang menentukan status sosial seseorang. Segala perbuatan maupun tindakan yang dilakukan manusia pastilah memiliki sebab dan akibat, begitu pula kejahatan, setiap kejahatan memiliki motif atau alasan untuk melakukan tindakan kejahatan dan setiap alasan tersebut pasti berbeda-beda satu sama lainnya. Perbedaan ini terjadi karena setiap orang memiliki kepentingan yang berbeda-beda pula. 
Media Komunikasi dan Informasi Hukum dan Masyarakat

Faktor-faktor timbulnya kejahatan, meringankan hukuman yang dijatuhkan khususnya kejahatan pencurian disebabkan: padanya.

\section{Faktor ekonomi}

Ekonomi merupakan salah satu hal yang penting di dalam kehidupan manusia, maka keadaan ekonomi dari pelaku tindak pidana pencurianlah yang sering muncul melatarbelakangi seseorang melakukan tindak pidana pencurian. Para pelaku sering tidak mempunyai pekerjaan yang tetap, atau bahkan tidak punya pekerjaan. Karena desakan ekonomi yang menghimpit, yaitu harus memenuhi kebutuhan keluarga, membeli sandang maupun pangan, atau ada sanak keluarganya yang sedang sakit, maka sesorang dapat berbuat nekat dengan melakukan tindak pidana pencurian.

Rasa cinta seseorang terhadap keluarganya yang menyebakan seseorang sering lupa diri dan akan melakukan apa saja demi kebahagiaan keluarganya. Terlebih lagi apabila faktor pendorong tersebut diliputi rasa gelisah, kekhawatiran, dan lain sebagainya, disebabkan orang tua (pada umumnya ibu yang sudah janda), atau isteri atau anak maupun anak-anaknya, dalam keadaan sakit keras memerlukan obat, sedangkan uang sulit di dapat sehingga seorang pelaku dapat termotivasi untuk melakukan pencurian.

Faktor ekonomi adalah faktor yang amat memegang peranan penting dalam kehidupan manusia, hal ini dikarenakan manusia memiliki kebutuhan (sandang, pangan, papan) yang harus dipenuhi setiap hari. Pemenuhan kebutuhan inilah yang membutuhkan biaya, jika kebutuhan sehari-hari sangat banyak, maka biaya yang dibutuhkan juga semakin banyak. Alasan tersebut sering dipergunakan para pelaku kejahatan karena alasan tersebut dapat
Terjadinya kejahatan pencurian ternak ini dikarenakan oleh faktor ekonomi dari pelaku yang masih tergolong rendah sedangkan kebutuhannya yang mendesak untuk dipenuhi. Tekanan atau desakan seperti itulah yang menyebabkan pelaku melakukan pencurian yang merupakan jalan pintas untuk memenuhi kebutuhannya. Ketidakseimbangan inilah yang menjadi faktor bagi setiap orang mencari alternative pekerjaan agar mendapatkan uang yang lebih banyak lagi sehingga dapat memenuhi kebutuhan hidup.

\section{Rendahnya penghayatan agama}

Agama merupakan norma yang meliputi nilai tertinggi dalam kehidupan umat manuisia dan dianggap sebagai kebutuhan spiritual yang hakiki. Dalam norma agama ini terdapat perintah-perintah dan laranganlarangan yang wajib ditaati oleh penganutnya. Walau pelaksanaan agama tersebut berbeda, namun pada dasarnya memiliki sesuatu persamaan yaitu larangan untuk melakukan setiap kejahatan.

Ajaran agama yang dianut seseorang harus diyakini kebenarannya agar dapat dijadikan sebagai pedoman dalam kehidupan secara pribadi yang pada akhirnya menumbuhkan keimanan yang berfungsi sebagai pengendali perilaku seseorang agar dapat terhindar dari perbuatan yang dilarang agama.

Penghayatan terhadap ajaran agama harus diberikan sejak dini hingga pada akhirnya dapat membentuk pola dan perilaku seorang anak. Agama sesuai dengan fungsi dan tujuannya merupakan hal yang kompleks 
Media Komunikasi dan Informasi Hukum dan Masyarakat

dalam kehidupan seseorang, karena menyangkut segi jasmaniah dan rohaniah. Maka dari itu agama dan perwujudannya mencakup dua segi yaitu memperbaiki, meluruskan dan mengharmoniskan sifat tabiat dan watak manusia kearah tujuan yang benar, sedang sisi lain agama menyinggung segi jasmaniah.

Kejahatan pencurian ternak yang dilakukan oleh seseorang juga tidak terlepas dari faktor lemahnya keimanan si pelaku, sebab jika iman seseorang itu kuat, sebesar apapun godaan dan dorongan untuk melakukan kejahatan akan dapat diatasi. Walau mungkin hukum dunia tidak mampu menjangkau pencurian malam hari yang dilakukan oleh seseorang, namun berkat keyakinannya terhadap ajaran agama dan mengingat hukum Tuhan, seseorang tidak akan berani melakukannya.

\section{Rendahnya Mental Dan Daya Emosional. \\ Keadaan mental seseorang adalah} sesuatu keadaan batin berupa cara berfikir dan berperasaan. Jika keadaan mental seseorang itu rendah, maka akan dapat mengakibatkan tingkah laku yang menyimpang. Dikaji lebih mendalam lagi maka dapat dikatakan bahwa keadaan mental seseorang itu dibangun oleh daya intelegensia ditambah dengan aturan-aturan moral agar seseorang dapat mengenal serta menilai suatu perbuatan. Pengertian intelegensi adalah merupakan suatu kumpulan kemampuan seseorang yang memungkinkan memperoleh ilmu pengetahuan dan mengamalkan ilmu tersebut dalam hubungan dengan lingkungan dan masalah-masalah yang timbul.
Keadaan tersebut juga turut dipengaruhi oleh daya emosional sebagai cerminan jiwa seseorang dalam menghadapi suatu masalah. Daya emosi yang terdapat dalam jiwa seseorang biasanya timbul dengan spontan serta mudah berubah (labil) serba ingin mengetahui dan mencoba sesuatu yang baru. Biasanya seoarang dewasa dalam bertindak dan berfikir secara matang dalam menghadapi suatu masalah.

$$
\text { Kaitanya dengan kejahatan }
$$

pencurian yang dilakukan oleh seseorang adalah bahwa orang tersebut tidak mampu menempatkan daya intelegensinya unutk menilai secara benar tentang baik buruknya perilaku yang dia lakukan. Rendahnya mental serta perasaan emosional ini mengakibatkan orang tersebut tidak mampu untuk mengendalikan diri sehingga banyak yang terjerumus dalam kejahatan kejahatan pencurian.

\section{Faktor Keluarga}

Pertumbuhan dan perkembangan seorang manusia pertama sekali terjadi dalam keluarga kemudian berkembang terus hingga dalam suatu masyarakat pada masa perkembangan, seorang anak akan sangat membutuhkan bimbingan dan pengarahan agar dapat menjalani masa-masa kritis kehidupan dengan baik.

Suatu keluarga yang berantakan dan bersikap acuh sesama anggota keluarganya akan menumbuhkan perasaan tidak tentram dan kekacauan dalam diri seseorang yang pada akhirnya akan timbul suatu sikap memberontak. Jika hal ini terjadi, maka orang tersebut lari dari kehidupan keluarganya untuk mencari kebebasan 
Media Komunikasi dan Informasi Hukum dan Masyarakat

sehingga terseret dalam perbuatan jahat, seperti kejahatan pencurian ternak.

Faktor lingkungan kehidupan keluarga dapat mempengaruhi terjadinya tindak pidana pencurian malam hari, jika keadaan kehidupan ekonomi keluarga tersebut sangat rendah atau kurang mencukupi dan juga apabila dalam kehidupan keluarga tersebut sering terjadi pertentangan atau percekcokan.

Pembentukan pribadi seseeorang, yang memegang peranan penting ialah keluarga atau orang tua. Lingkungan keluarga merupakan tempat pendidikan yang pertama dan utama.

\section{Faktor Lingkungan/Pergaulan}

Lingkungan pergaulan sehari-hari seseorang sangat besar sekali pengaruhnya terhadap perkembangan jiwa seseorang. Faktor kehidupan pergaulan dapat mempengaruhi seseorang untuk melakukan tindak pidana kejahatan pencurian, seperti misalnya bergaul dengan para penjudi, para pecandu narkotika atau minuman keras dan ataupun bergaul dengan para penjahat (residivis).

\section{Akibat Pengangguran}

Pengangguran adalah merupakan salah satu faktor penyebab timbulnya kejahatan. Bila dilihat jumlah angka pengangguran setiap tahunnya terus bertambah, hal ini tidak terlepas karena keadaan ekonomi keluarga yang minim dalam memenuhi kebutuhan.

\section{Pengaruh media massa khususnya TV dan film asing}

Media massa sebagai suatu alat atau sarana untuk suatu komunikasi secara massal dapat mempengaruhi tingkah laku dalam masyarakat. Seharusnya tujuan dari pemberitaan media massa baik surat kabar maupun majalah mengenai kejahatan dan bentuknya adalah berupa memberitahukan kepada masyarakat adanya kejahatan dan dengan pemberian itu diharapkan agar masyarakat dapat menghindarkan diri atau berusaha untuk tidak menjadi korban kejahatan. Tetapi tujuan ini sering disalahgunakan. Banyak penjatah malah meniru tehnik-tehnik melakukan kejahatan yang dimuat dalam mass media yang diberitakan secara berlebih-lebihan.

Pemberitaan dalam surat kabar atau majalah perbuatan jahat serta modus operandinya dapat mempengaruhi timbulnya keinginan untuk melakukan kejahatan serupa karena mereka telah mengetahuinya. Dari media massa juga dapat mengetahui bagaimana reaksi dari masyarakat terhadap kejahatan khususnya kejahatan kejahatan pencurian.

Adanya kecenderungan masyarakat terutama kalangan orang-orang muda lebih menyenangi film-film asing yang bertemakan kekerasan, misalnya melakukan pencurian malam hari dengan menggunakan cara dan alat-alat yang canggih, memang hal ini memberikan kesan dan rasa kagum bagi penontonnya. Tetapi dibalik semua ini dapat menjadi dorongan dan ide baru untuk menerapkan cara-cara terbaik dalam melakukan kejahatan karena mereka telah mengetahui cara pelaksanaannya.

Jelaslah bahwa alat media sebagaimana juga lingkungan keluarga dan pergaulan dapat berubah menjadi faktor kriminal apabila informasi dan pengujiannya penuh diliputi oleh rangsangan yang bersifat kriminal.

\section{Pengaruh alkohol.}

Alkohol atau minuman yang memabukkan juga dapat menyebabkan 
Media Komunikasi dan Informasi Hukum dan Masyarakat

untuk membuat kejahatan. Pada saat seseorang dalam keadaan mabuk, kendali dalam dirinya tidak ada lagi. Perasaan takutnya telah hilang dan tidak memikirkan resiko dari apa yang dia lakukan. Demikian juga halnya terhadap kajahatan kejahatan pencurian, seorang yang telah mabuk tidak dapat membedakan lagi mana yang baik dan mana yang buruk, sehingga akan melakukan apa saja.

\section{Faktor Kesempatan}

Selain faktor tersebut di atas, faktor situasi dan kondisi pada waktu melakukan kejahatan pencurian merupakan salah satu faktor yang mendorong dilakukannya tindak pidana kejahatan pencurian. Situasi dan kondisi di sini adalah faktor-faktor atau keadaankeadaan yang memungkinkan pelaku untuk melakukan tindak pidana kejahatan pencurian. Faktor-faktor atau keadaan dimaksud seperti:

a. Faktor objektif, yaitu :

1.Ada barang/benda hasil kejahatan pencurian

2.Barang/benda itu memungkinkan untuk disimpan

b. Faktor subjektif, yaitu pelaku telah mempersiapkan dan mempelajari daerahdaerah sasaran yang dituju seperti mempersiapkan alat-alat yang akan dipergunakan, waktu pelaksanaan, serta keadaan-keadaan yang menghalangi kejahatan pencurian.

Barda Nawawi Arief menyebutkan penyebab terjadinya kejahatan adalah :

1. Kemiskinan, pengangguran, buta huruf (kebodohan), ketiadaan atau kekurangan perumahan yang layak dan sistem pendidikan serta latihan yang tidak cocok/serasi.
2. Meningkatnya jumlah penduduk yang tidak mempunyai prospek (harapan) karena proses integrasi sosial, juga karena memburuknya ketimpanganketimpangan sosial.

3. Mengendurnya ikatan sosial dan keluarga.

4. Keadaan-keadaan/kondisi yang menyulitkan bagi orang-orang yang beremigrasi ke kota-kota atau ke negara-negara lain.

5. Rusaknya atau hancurnya identitas budaya asli yang bersamaan dengan adanya rasisme dan diskriminasi menyebabkan kerugian/kelemahan di bidang sosial, kesejahteraan dan lingkungan pekerjaan.

6. Menurun atau mundurnya (kualitas) lingkungan perkotaan yang mendorong peningkatan kejahatan dan berkurangnya (tidak cukupnya) pelayanan bagi tempat-tempat fasilitas lingkungan/bertetangga.

7. Kesuitan-kesulitan bagi orang-orang dalam masyarakat modern untuk berintegrasi sebagaimana mestinya di dalam lingkungan masyarakatnya, di lingkungan keluarga/familinya, tempat pekerjaannya atau di lingkungan sekolahnya.

8. Penyalahgunaan alkohol, obat bius dan lain-lain yang pemakaiannya juga diperluas karena faktor-faktor yang disebut di atas.

9. Meluasnya aktivitas kejahatan yang terorganisasi, khususnya perdagangan obat bius dan penadahan barangbarang curian.

10. Dorongan-dorongan (khususnya oleh mass media) mengenai ide-ide dan 
Media Komunikasi dan Informasi Hukum dan Masyarakat

sikap-sikap yang mengarah pada tindakan kekerasan, ketidaksamaan (hak) atau sikap-sikap tidak toleran (intoleransi). ${ }^{11}$

\section{B. Penerapan Sanksi Hukum Pidana Terhadap Pidana Pelaku Tindak Pidana Pecurian Hewan Ternak}

\section{Pertanggungjawaban Pidana}

Berbicara tentang penerapan sanksi hukum pidana pada dasarnya berbicara tentang pertanggungjawaban pidana yang tidak dapat dilepaskan dariperbuatan pidana. Orang tidak mungkin dipertanggungjawabkan untuk dipidana, apabila ia tidak melakukan tindak pidana. Unsur tindak pidana dan kesalahan (kesengajaan) adalah unsur yang sentral dalam hukum pidana. Unsur perbuatan pidana terletak dalam lapangan objektif yang diikuti oleh unsur sifat melawan hukum, sedangkan unsur pertanggungjawaban pidana merupakan unsur subjektif yang terdiri dari kemampuan bertanggung jawab dan adanya kesalahan (kesengajaan dan kealpaan).

Adanya pertanggungjawaban pidana diperlukan syarat bahwa pembuat mampu bertanggung jawab. Tidaklah mungkin seseorang dapat dipertanggungjawabkan apabila ia tidak mampu bertanggung jawab. ${ }^{12}$ Dapat dipidananya si pelaku, disyaratkan bahwa tindak pidana yang dilakukannya itu memenuhi unsur-unsur yang telah ditentukan dalam Undang-undang. Dilihat dari sudut terjadinya tindakan yang dilarang, seseorang akan dipertanggungjawabkan atas tindakan-tindakan

${ }^{11}$ Barda Nawawi Arief, Bunga Rampai Kebijakan Hukum Pidana, Citra Aditya Bhakti, Bandung, 2005, hal.4445.

12 Sudarto, Hukum Pidana, Yayasan Sudarto, Semarang, 2000, hal. 56 tersebut, apabila tindakan tersebut melawan hukum serta tidak ada alasan pembenar atau peniadaan sifat melawan hukum untuk pidana yang dilakukannya. Dan dilihat dari sudut kemampuan bertanggungjawab maka hanya seseorang yang mampu bertanggungjawab yang dapat dipertanggungjawabkan atas perbuatannya. Tindak pidana jika tidak ada kesalahan adalah merupakan asas pertanggungjawaban pidana, oleh sebab itu dalam hal dipidananya seseorang yang melakukan perbuatan sebagaimana yang telah diancamkan, ini tergantung dari soal apakah dalam melakukan perbuatan ini dia mempunyai kesalahan.

Berdasarkan hal tersebut maka pertanggung jawaban pidana atau kesalahan menurut hukum pidana, terdiri atas tiga syarat yaitu:

1. Dapat dipertanggungjawabkan kepada si pembuat atau kemampuan bertanggungjawab dari si pembuat.

2. Ada hubungan tertentu dalam batin orang yang berbuat, baik dalam bentuk kesengajaan maupun kealpaan.

3. Tidak ada dasar alasan yang menghapus pertanggungjawaban si pembuat atau tidak ada alasan penghapusan kesalahan. ${ }^{13}$

Pertanggungjawaban pidana diartikan sebagai diteruskannya celaan yang objektif yang ada pada perbuatan pidana dan secara subjektif yang ada memenuhi syarat untuk dapat dipidana karena perbuatannya itu. Dasar adanya perbuatan pidana adalah asas legalitas, sedangkan dasar dapat dipidananya pembuat adalah asas kesalahan. Ini berarti pembuat perbuatan pidana hanya akan dipidana jika ia mempunyai kesalahan dalam melakukan perbuatan pidana tersebut.

${ }^{13} \mathrm{lbid}$, hal. 58 
Media Komunikasi dan Informasi Hukum dan Masyarakat

Tindak pencurian ternak apabila ditinjau dari aspek hukum pidana positif Indonesia, maka perbuatan tersebut dapat dikategorikan sebagai suatu tindak pidana, karena hukum pidana positif Indonesia selain mengatur mengenai kepentingan antar individu juga dengan negara selaku institusi yang memiliki fungsi untuk melindungi setiap warga negaranya, dalam hal ini seseorang yang telah menjadi korban dari suatu tindak pidana. Pada dasarnya untuk menentukan seseorang telah melakukan suatu tindak pidana atau tidak, maka harus memenuhi unsur-unsur tindak pidana, yaitu:

a. Adanya suatu perbuatan

b. Perbuatan tersebut dilarang oleh undang-undang

c. Perbuatan tersebut diancam dengan pidana

d. Perbuatan tersebut dapat dipertanggung jawabkan oleh pelaku

\section{Penerapan Sanksi Hukum Pidana Terhadap Pelaku Tindak Pidana Pencurian Hewan Ternak.}

Pelaku tindak pidana pencurian
ternak dapat diberikan sanki atas
perbuatannya atau dengan kata lain harus dilakukan penegakan hukum terhadap pelaku pencurian hewan ternak. Secara konseptional, maka inti dan arti penegakan hukum terletak pada kegiatan menyerasikan hubungan nilai-nilai yang terjabarkan di dalam kaidah-kaidah yang mantap dan sikap tindak sebagai rangkaian penjabaran nilainilai tahap akhir untuk menciptakan, memelihara dan mempertahankan kedamaian pergaulan hidup.

Hukum merupakan tumpuan harapan dan kepercayaan masyarakat untuk mengatur pergaulan hidup bersama. Hukum merupakan perwujudan atau manifestasi dari nilai-nilai kepercayaan. Oleh karena itu penegakan hukum diharapkan sebagai orang yang sepatutnya dipercaya dan menegakan wibawa hukum yang pada hakekatnya berarti menegakkan nilai-nilai kepercayaan di dalam masyarakat. ${ }^{14}$

Kebijakan yang akan ditempuh akan mencakup bidang kegiatan penegakan hukum pertama-tama ditujukan guna meningkatkan ketertiban dan kepastian hukum dalam masyarakat. Dalam rangka ini maka akan dimantapkan penyempurnaan sistem koordinasi serta penyerasian tugas-tugas instansi aparat penegak hukum. hal ini dilakukan antara lain dengan menertibkan fungsi, tugas, kekuasaan dan wewenang lembaga-lembaga yang bertugas menegakkan hukum menurut profesi ruang lingkup masing-masing serta didasarkan atas sistem kerja sama yang baik.

Pelaku tindak pidana pencurian ternak dapat dipertanggung jawabkan atas perbuatannya sebagaimana diatur dalam Pasal 363 KUHP disertai dengan salah satu keadaan seperti berikut:

1. Barang yang dicuri itu adalah hewan. Hewan sebagaimana diterangkan dalam Pasal 101 ialah semua jenis binatang yang memamah biak (kerbau, lembu, kambing, dan sebagainya), binatang yang berkuku satu (kuda, kedelai) dan babi. Kucing, anjing, ayam, itik, dan angsa tidak termasuk hewan, karena tidak memamah biak, tidak berkuku satu, dan bukan pula sejenis babi.

2. Pencurian itu dilakukan pada waktu sedang terjadi bermacam-macam bencana, seperti kebakaran, peletusan, banjir, gempa bumi atau gempa laut, peletusan gunung berapi, kapal karam, kapal terdampar, kecelakaan kereta api, huru-hara, pemberontakan atau bahaya perang. Pencurian yang dilakukan dalam waktu seperti ini diancam hukuman lebih berat, karena pada waktu semua orang sedang menyelamatkan jiwa dan raganya serta harta bendanya, si pelaku

${ }^{14}$ CST. Kansil, Pengantar IImu Hukum dan Tata Hukum Indonesia, Balai Pustaka, Jakarta, 1998, hal.29 
mempergunakan kesempatan itu untuk melakukan kejahatan, yang menandakan bahwa orang itu adalah rendah budinya. Tentang kapal ini dapat dilihat pada Pasal 95 KUHP dan tentang pemberontakan dapat di lihat pada Pasal 96 KUHP. Pencurian yang dilakukan dalam waktu seperti ini perlu dibuktikan, bahwa antara terjadinya bencana dengan pencurian itu ada kaitan yang erat, sehingga dapat dikatakan bahwa pencuri tersebut mempergunakan kesempatan itu untuk mencuri. Berbeda hal nya seorang pencuri yang melakukan pencurian di dalam sebuah rumah di bagian kota, yang kebetulan di bagian kota itu terjadi kebakaran. Tindak pidana ini tidak dapat digolongkan dengan pencurian yang dimaksud oleh pasal ini, karena disini si pencuri tidak sengaja menggunakan kesempatan peristiwa kebakaran yang terjadi pada waktu itu.

3. Pencurian itu dilakukan pada waktu malam dalam sebuah rumah atau di pekarangan tertutup yang ada rumahnya, dilakukan oleh orang yang ada di situ tiada dengan setahunya atau tiada dengan kemauannya yang berhak.

Waktu malam sebagaimana dimaksud oleh Pasal 98 KUHP adalah waktu antara matahari terbenam dan terbit kembali. Makna rumah disini ialah bangunan yang dipergunakan sebagai tempat tinggal siang dan malam. Gudang dan toko yang tidak didiami pada waktu siang dan malam, tidak termasuk dalam pengertian rumah, sebaliknya gubug, gerbong kereta api dan petakpetak kamar di dalam perahu, apabila didiami siang dan malam, termasuk dalam pengertian rumah. Pengertian pekarangan tertutup di sini ialah dataran tanah yang pada sekelilingnya ada pagarnya (tembok, bambu, pagar tumbuhtumbuhan yang hidup) dan tanda-tanda lain yang dapat dianggap sebagai batas. Untuk dapat dituntut dengan pasal ini, si pelaku pada waktu melakukan pencurian itu harus masuk ke dalam rumah atau pekarangan tersebut. Apabila hanya menggaet saja dari jendela, tidak dapat digolongkan dengan pencurian yang dimaksud di sini.

4. Pencurian itu dilakukan oleh dua orang atau lebih secara bersama-sama. Supaya dapat dituntut menurut pasal ini, maka dua orang atau lebih itu harus bertindak bersamasama sebagaimana dimaksud oleh Pasal 55 KUHP, yakni:

a. Orang yang melakukan, yang menyuruh melakukan atau yang turut melakukan perbuatan itu. b. Orang yang dengan pemberian upah, perjanjian, salah memakai kekuasaan atau martabat, memakai paksaan, ancaman atau tipu karena memberi kesempatan, ikhtiar atau keterangan, dengan sengaja menghasut supaya perbuatan itu dilakukan, namun dalam hal ini orang yang boleh diminta pertanggungjawaban kepadanya hanyalah perbuatan yang sengaja dibujuk olehnya serta akibat perbuatan itu.

Hewan ternak yang dimaksud didalam pasal 363 KUHP adalah semua jenis binatang yang memamah biak (kerbau, lembu, kambing, dan sebagainya), binatang yang berkuku satu (kuda, kedelai) dan babi. Kucing, anjing, ayam, itik, dan angsa tidak termasuk hewan, karena tidak memamah biak, tidak berkuku satu, dan bukan pula sejenis babi.

\section{Kesimpulan dan Saran}

\section{A. Kesimpulan}

1. Faktor-faktor yang menyebabkan terjadinya tindak pidana pencurian hewan ternak adalah faktor ekonomi faktor ekonomi, rendahnya penghayatan agama, faktor keluarga, faktor lingkungan/pergaulan, akibat pengangguran, pengaruh media massa khususnya tv dan film asing, pengaruh alcohol, faktor kesempatan. Selain faktor tersebut terdapat faktor-faktor lainya yaitu : Faktor objektif seperti ada barang/benda hasil kejahatan pencurian barang/benda itu memungkinkan untuk disimpan serta faktor subjektif, yaitu pelaku telah mempersiapkan dan mempelajari daerah-daerah sasaran yang dituju seperti mempersiapkan alat-alat yang akan dipergunakan, waktu pelaksanaan, serta keadaan-keadaan yang menghalangi kejahatan pencurian. 
Media Komunikasi dan Informasi Hukum dan Masyarakat

2. Penerapan sanksi hukum pidana terhadap pelaku tindak pidana pencurian hewan diatur dalam Pasal 363 KUHP disertai dengan salah satu keadaan seperti berikut: barang yang dicuri itu adalah hewan. Hewan sebagaimana diterangkan dalam Pasal 101 ialah semua jenis binatang yang memamah biak (kerbau, lembu, kambing, dan sebagainya), binatang yang berkuku satu (kuda, kedelai) dan babi. Kucing, anjing, ayam, itik, dan angsa tidak termasuk hewan, karena tidak memamah biak, tidak berkuku satu, dan bukan pula sejenis babi.

\section{B. Saran}

1. Dalam pemberian pidana hendaknya perlu juga memperhatikan hal-hal pemberat dan peringan pidana, dan manfaat dari putusan tersebut dan jangan hanya melihat dan menitikberatkan hukuman atas kesalahan dan sisi kemanusiaannya.

2. Terjadinya tindak pidana pencurian ternak tidak terlepas dari sanksi yang ringan terhadap para pelakunya, karena itu disarankan agar agar aparat penegak hukum memberikan sanksi hukuman yang berat terhadap pelaku tindak pidana ternak sehingga mereka tidak mengulangi perbuatannya lagi dan orang-orang yang akan melakukan perbuatan tersebut menjadi takut berbuat pencurian ternak

\section{DAFTAR PUSTAKA}

Abdul Kadir Muhammad, Hukum dan Penelitian Hukum, Citra Aditya Bakti, Bandung, 2004.

Bambang Sunggono, Metodologi Penelitian Hukum, Raja Grafindo Persada, Jakarta, 1997.

Bambang Waluyo, Penelitian Hukum Dalam Praktek, Sinar Grafika, Jakarta, 1996.

Barda Nawawi Arief, Bunga Rampai Kebijakan Hukum Pidana, Citra Aditya Bhakti, Bandung, 2005.

Bismar Nasution, Metode Penelitian Hukum Normatif dan Perbandingan Hukum, Makalah disampaikan pada Dialog Interaktif tentang Penelitian Hukum dan Hasil Penulisan Hukum pada Majalah Akreditasi, Fakultas Hukum USU, Medan, Tanggal 18 Pebruari 2003.

C.T.S Kansil.Pengantar IImu Hukum dan Tata Hukum Indonesia. Balai Pustaka, Jakarta, 1998.

Kartini Kartono, Patalogi Sosial Jilid I, PT Raja Grafindo Persada, Jakarta, 2003.

Mochtar KusumaAtmadja, Konsep-Konsep Hukum Dalam Pembangunan, Alumni, Bandung, 2002.

Soerjono Soekanto, Sosiologi Suatu Pengantar, Raja Grafindo Persada, Jakarta, 2007.

Sudarto, Hukum Pidana, Yayasan Sudarto, Semarang, 2000. 